\title{
Przysłowia na jubileusz sześćdziesięciolecia Katedry Dydaktyki Języka i Literatury Polskiej
}

Mówią, że kto wiatr sieje, będzie zbierał burzę, za to, gdy ziarno dobre, plony będą duże.

Bywa, że z wielkiej chmury deszcz nie spadnie wcale.

Lecz gdy początek skromny, koniec chodzi w chwale.

Dzisiejsza Jubilatka ma historię długą

znaczoną wspólną pracą i wspólną zasługą

tych, co ją lat sześćdziesiąt wiedli rok po roku, idąc ku dobrej sławie od pierwszego kroku.

Miterę-Dobrowolską ${ }^{1}$ oraz Cofalika ${ }^{2}$

i Tabakowską ${ }^{3}$ wspomnieć wypada. Wynika

z kolei rzeczy, że jest takich coraz więcej,

o których dobre słowo rzec trzeba w podzięce, jak o Adamczykowej ${ }^{4}$. Nie starczą dwie słowie,

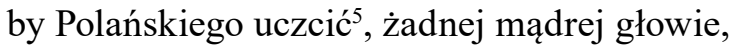
tak wiele ma osiągnięć. Dochodzi do tego

wkład, który wnoszą Aniołki Ediego:

${ }^{1}$ Mieczysława Mitera-Dobrowolska - twórczyni Katedry Metodyki Nauczania Literatury i Języka Polskiego, pierwszy długoletni kierownik tej Katedry (1958-1970).

2 Jan Cofalik - autor wielu prac dydaktycznych, kierownik Katedry w latach 1971-1973.

${ }^{3}$ Irena Tabakowska — dydaktyk języka, współautorka (z Janem Cofalikiem) pionierskiej publikacji Ksztaltowanie języka ucznia w procesie nauczania języka polskiego (1966).

${ }^{4}$ Zofia Szmytrowska-Adamczykowa - dydaktyk literatury, wybitna specjalistka zagadnień literatury dziecięcej.

${ }^{5}$ Edward Polański — znawca ortografii, kierownik Katedry w latach 1973-2002. 
Helenka, obie Ewy, Benia i Danusia ${ }^{6}$, a także fruwająca dziś gdzie indziej Usia? A i z aniołków wnuków każdy latać może górnie, Archaniołami bądźcie! Daj wam Boże! Co na początku małą grupka ludzi było po latach się w gromadę zacną przerodziło, co falą czasu płynąć, sukces za sukcesem zalicza. Navigare enim est necesse!

W chwale więc jubileusz dzisiaj swój obchodzi Katedra, a co dobre, to się uczcić godzi!

Gdy teraźniejszość rękę podaje przeszłości, by ją przypomnieć, na myśl przychodzą mądrości, co w przysłowiach zawarte i w skrzydlatych słowach. W nich się prawda, przestroga i proroctwo chowa. Co od pierwszego kroku dobrze się zaczęło, owoc dało obfity. Koniec wieńczy dzieło. Taki rezultat, który cyklu nie zamyka. Wszak rozwija się bujnie nadal dydaktyka polonistyczna. To zaś i Katedrze wróży trwanie do końca świata i jeden dzień dłużej. Nie przeminie, nie zniknie, co nadal osiąga, sic transit gloria mundi. Tak. Ale ars longa!

Ci zaś, co uniwersyteckiej dobro Rzeczy, pełniąc swój urząd chlubnie, winni mieć w swej pieczy, niech nie zapomną: postęp, by mógł się narodzić, ze zmianą musi tradycja w jednej parze chodzić. Kołłątaj wyższym szkołom zostawił sukcesję: nauczycielską niechaj otoczą profesję opieką. Oświatę, uczniów oraz nauczanie.

Nadal obowiązuje to ważne przesłanie.

Katedry to jest rola edukację wspierać.

Może swą nazwę zmienić, inny szyld przybierać, ale zniknąć nie może. Nikt i nic nie zdoła

${ }^{6}$ Helena Synowiec - dziś profesor językoznawstwa, wybitny dydaktyk języka; obie Ewy: Ewa Ogłoza - literaturoznawczyni, badaczka tekstów Andersena; Ewa Jaskółowa - literaturoznawczyni, popularyzatorka interpretacji literackiej w szkole; Benia — Bernadeta Niesporek-Szamburska, językoznawczyni, dydaktyk języka i glottodydaktyk; Danusia - Danuta Krzyżyk, językoznawczyni, dydaktyk języka.

${ }^{7}$ Usia - Urszula Żydek-Bednarczuk, profesor językoznawstwa, przez wiele lat pracowała w Katedrze Dydaktyki Języka i Literatury Polskiej. 
zrozumieć lepiej, czego potrzebuje szkoła.

Gdy się zmianę wprowadza, ryzyko istnieje, że co lepsze się zdaje, wcale takie nie jest.

Nie jest grzechem pomyłka, ale trwanie w błędzie.

Gdy poprawa jest trudna, niech pociechą będzie prawda, którą powtarza wciąż przysłowie stare: mówiące, że humanum semper est errare.

A decydent również sobie uprzytomnia:

Vanitas vanitatum et vanitas omnia.

A co najważniejsze - Omnia mea mecum.

Czyli rozum i serce. Pamiętaj, człowieku!

Tak zwanym nieomylnym zaś przypomnieć pora:

Ostrożnie! Wszak klasztora dłużej niż przeora.

Dla twardzieli przysłowie mają zaś ludziska jako przestrogę: przyjdzie kryska na Matyska!

A nie będzie też przesady

Mickiewicza wspomnieć Dziady:

„A kto prośby nie posłucha, W imię Ojca, Syna, Ducha". I ,a kysz!”, zaś groźba taka wstrząsa sumieniem Polaka!

Chcąc zaś nie przysłowiami nudzić zacnych gości, czas do dzisiejszej wrócić znów uroczystości.

Gdy serce rocznicowa napełnia otucha, że będzie dobrze, mądry, kto na zimne dmucha, nie zasypiając i gruszek w popiele.

Więc wszystkiego dobrego i sukcesów wiele! Niech dzisiejszego święta wszyscy uczestnicy spotkają się z okazji kolejnej rocznicy!

A że się różnie wszystko na tym świecie plecie, Będzie święcić Katedra też swoje stulecie!

Jadwiga Kowalikowa

Katowice, 17 czerwca 2019 roku 